Cadernos de Arquitetura e Urbanismo, v.17, n.21, 20 sem. 2010 
1. Arquiteta, mestre e doutora em filosofia pela UFMG, professora adjunta da PUC Minas, coordenadora do Opur/ Proex-PUC Minas, pesquisadora do Observatório das Metrópoles. Este artigo é parte da pesquisa "Pedagogia Urbana, Espaços de autonomia", em desenvolvimento no período 2010-2012, que conta com auxílio financeiro (APQ) do CNPq. 


\title{
EXPERIÊNCIA ESTÉTICA, ARQUITETURA URBANA
}

\author{
AESTHETIC EXPERIENCE, URBAN ARCHITECTURE
}

Rita de Cássia Lucena Velloso

\begin{abstract}
Resumo
O que significa colocar lado a lado os termos "experiência estética" e "arquitetura urbana"? Juntas, as duas expressões pretendem identificar uma posição bem específica no modo de compreender e falar sobre a cidade. O estético designa o elemento da experiência humana mais comum - o universo de suas sensações -, e aqui assumo que, quando se trata de definir uma cidade, a experiência vivida é mais fundamental que as formas construídas. Trato aqui de descrever a experiência estética em sua circunstância, segundo a ação que a caracteriza e o habitante urbano que a realiza em sua vida cotidiana. Por sua vez, o conceito de arquitetura urbana carrega consigo as formulações de Walter Benjamin em seus escritos sobre a vida numa grande cidade, os quais afirmam a primazia da experiência humana como o aspecto mais fundamental em qualquer definição de urbanismo. Para além de desenho urbano, planejamento urbano, estudos urbanos, história urbana, teoria urbana ou outros termos especializados, arquitetura urbana designa um campo discursivo que articula todas essas disciplinas numa compreensão multidimensional da cidade.
\end{abstract}

Palavras-chave: Experiência estética; Walter Benjamin; Vida cotidiana.

\begin{abstract}
What do we mean by aesthetic experience related to urban architecture? These two expressions together identify a special position in understanding and approaching the city. Aesthetics speaks to this element of ordinary human experience, assuming that lived experience should be more important than physical form in defining the city. Urban architecture is a term that also carries with it important echoes of the philosopher Walter Benjamin's writings on Paris. His formulation emphasizes the primacy of human experience as the fundamental aspect of any definition of urbanism. Rather than urban design, urban planning, urban studies, urban history, urban theory, or other specialized terms, urban architecture identifies a broad discursive arena that combines all these disciplines as well as others into a multidimensional consideration of a city.
\end{abstract}

Key words: Aesthetic experience; Walter Benjamin; Everyday life. 
2. "Die Architektur bot von jeher den prototyp eines Kunstwerks, dessen

Rezeption in der Zeerstreuung und durch das Kolletivum erfolgt"

(BENJAMIN, Walter. Das Kunstwerk

im Zeitalter seiner technischen

Reproduzierbarkeit. In: GS I.2, (431508), p. 465). Também em BENJAMIN,

1987, v. I, p. 165-196: A obra de arte

à época de sua reprodutibilidade técnica, p. 193. tradução modificada.

3. PIAGET, J. "Perceptual and cognitive (or operational) structures in the development of the concept $f$ space in the child," Proceedings of the XIV International Congress of Psychology. Piaget (1896-1980) produziu uma larga pesquisa sobre a construção da representação do espaço no mundo intrapsíquico individual, permitindo, no escopo de sua teoria, muitos modos de leitura do processo de construção e uso do espaço em culturas diversas.

Cadernos de Arquitetura e Utbanismo, v.17, n.21, 20 sem. 2010

\section{Premissas}

Walter Benedix Schönflies Benjamin, um alemão nascido na moderna Berlim oitocentista, escreveu em meados da década de 1930 que a arquitetura fora desde sempre "o protótipo de uma obra de arte cuja recepção se dá coletivamente sob o critério da distração,"2 afirmativa que trazia para o primeiro plano o sentido da obra definida não a partir de sua matéria formada, mas segundo seu aspecto receptivo. Os pontos de fuga dessa perspectiva que o filósofo desenha são, de um lado, a ideia de uma obra sempre experimentada por um sujeito coletivo e, de outro, o modo de tal experiência desenrolar-se, isto é, não mais a contemplação que tradicionalmente demarcava a fruição de uma obra, mas a desatenção. À luz do ensaio sobre a obra de arte, em que Benjamin se pronuncia sobre a arquitetura, também sobre esta, examino seu caráter de experiência estética, estabelecendo o problema central do trabalho a partir dos termos em que o próprio Benjamin argumenta, quais sejam, a constituição (a natureza) dessa experiência e o modo de percepção (a ação) do sujeito que a realiza.

O que está envolvido num conceito de arquitetura como experiência estética? Uma peculiar relação estabelecida entre indivíduo e obra é o que circunscreve, primeiramente, o que podemos chamar experiência arquitetural. Nela, o espaço é o elemento mediador entre sujeito e obra e ao mesmo tempo substância da obra arquitetônica. Mas, para além do arquitetônico o espaço é uma espécie de fundo sobre o qual todos os atos se destacam. A espacialidade, que, segundo Fiona Hughes, é o horizonte indeterminado dentro do qual surge toda e qualquer experiência (HUGHES, 1999, p. 133), demanda uma percepção que é sempre primeiramente vaga, imprecisa e escassa, para a posteriori afinar-se em situações que vão das mais familiares (quando apenas traços perceptuais nos bastam para lidar com objetos) até as mais inesperadas (situações novas ou que se desenrolam apenas uma vez, quando nos são exigidos dados perceptuais para a adaptação ao que se nos oferece). O mecanismo da percepção do espaço opera sobre uma base de intenções gerais e cotidianas, resultando numa construção gradual que é "consciência do espaço", a qual não se constitui a partir de uma "leitura ou apreensão das propriedades dos objetos, mas, desde o princípio, uma ação que exercemos sobre os objetos."3 A percepção espacial constroi-se por meio da lida com coisas em seus respectivos tamanho, posição e distâncias.

Na relação indivíduo/obra é necessário dar relevo ao aspecto receptivo (aesthesis) da experiência estética, detendo-se no modo como a atitude do receptor está implicada na obra, assumindo como recepção aquilo que é determinado na medida da pergunta que o receptor dirige à obra. Essa pergunta, quando se trata do espaço, tem como ponto de chegada a localização, que remete à intermediação entre os objetos e os sentidos humanos. $O$ mundo revelado no espaço percebido é da ordem do sensível: do visível, do audível, do tangível. Numa palavra, é da ordem do corpo. Enquadrando a pergunta que um indivíduo dirige aos objetos a partir de suas configuração e localização, faz-se o laço entre o corpo e o espaço. É primeiramente o corpo que o experimenta - corpo como primeira realidade, como vivido imediato da 
4. "Cette activité suppose une perception sensible orientée par une attention cultivée dépendente d'une situation et de circonstances socioculturelles déterminées. L'expérience esthétique est alors le lieu d'une apprehension de soi qui inscrit la subjectivité dans la communauté culturelle" (CAUNE, 1997).

Cadernos de Arquitetura e Urbanismo, v.17, n.21, $2^{0}$ sem. 2010 consciência, sem distância ou objetivação. Como realidade física o corpo está desde sempre situado no mundo, localizado espacialmente; assim, atua como estrutura da subjetividade constantemente operante no relacionamento com o mundo.

É o corpo quem dá a medida da relação do indivíduo com o mundo, a que se pode chamar "estética"; é o corpo "e suas funções que dão ao estético sua preeminência como operação guiada pelo sensório" (CAUNE, 1997). No domínio estético trata-se não apenas de um estado emocional do sujeito, mas da relação com um outro, configurada no contato afetivo com o mundo. Esse contágio é a apreensão estética: a síntese em aberto da combinação de afecção e reflexão. Oscilo entre apreender e refletir, isto é, entre estar afetado por e raciocinar a respeito de algo. Dá-se uma peculiar combinação entre percepção sensorial e pensamento, em que, como afirma Fiona Hughes, "sou tomado pelo objeto (...), estou encantada com esse objeto: não vou abandoná-Io" (HUGHES, 1999, p. 135).

Nos contornos que a delineiam como capacidade de perceber as qualidades materiais das coisas do mundo, a experiência estética não é, a rigor, exclusiva do âmbito da arte. Experimentar esteticamente diz respeito a mobilizar meu corpo e minhas faculdades mentais enquanto sou afetada pelos objetos. Não há experiência estética sem esse movimento do eu para fora de si: algo do objeto desperta a minha atenção sensorial quando se destaca do mundo, deixando em mim uma impressão, de tal modo que sou obrigada a me mover em sua direção, a ele respondendo corporalmente. O corpo opera para caracterizar a comunicabilidade do estético (katharsis), aquilo que, na experiência, implica um retorno do sujeito sobre si. ${ }^{4}$ Meu corpo materializa aquilo que me é próprio, conjunto de tecidos e órgãos, suporte da vida psíquica, sofrendo também as pressões do social, do institucional, do jurídico. É pelo corpo que o sentido é percebido: ele é o peso suportado na experiência que faço das coisas.

Eu me esforço menos para apreendê-lo que para escutá-lo no nível (...) da percepção cotidiana, ao som dos seus apetites, de suas penas e alegrias: contração e descontração dos músculos; tensões e relaxamentos internos, sensações de vazio, de pleno, de turgescência, mas também um ardor ou sua queda, o sentimento de uma ameaça ou, ao contrário, de segurança íntima, abertura ou dobra afetiva, opacidade ou transparência, alegria ou pena provindas de uma difusa representação de si próprio (ZUMTHOR, 2000, p. 29).

A demarcação da estética prioritariamente entendida e qualificada em termos de sensibilidade, consolidada no século XVIII - quando se assiste a uma redução do valor gnosiológico da experiência estética (FERRARIS, 1990, p. 171-214) - pode ser reconduzida à arquitetura por meio de uma análise das formas históricas de sua recepção. Tendo surgido inicialmente no século XVIII como uma discussão sobre sentimentos que edifícios e jardins provocavam em pessoas, o ato da recepção em arquitetura foi desenvolvido nas estéticas do pitoresco e do sublime, pela filosofia do empirismo inglês, e na teoria francesa da arquitetura, por arquitetos como Marc-Antoine Laugier, Germain Boffrand, Le Camus de Mézière. Naquele momento, num tipo de pensamento denominado por alguns autores como "estética arquitetônica 
5. Penso, por exemplo, nos projetos habitacionais na Alemanha dos anos 1920: Weissenhof Siedlung, DessauTorten e o experimento da Cozinha de

Frankfurt

6. A cidade industrial é fundamento da sociedade capitalista. A revolução industrial, começada na Inglaterra ao final do século XVIII, foi um processo pelo qual passaram França, Alemanha e Estados Unidos no século XIX

As economias de mercado desde

o início se inscrevem na economia mundial, enfrentando a concorrência.

$\mathrm{Na}$ Inglaterra setecentista havia

considerável oferta de mão de obra, esta mesma, de resto, resultado de uma longa história de expropriação.

7. "A poiesis, a aesthesis e a catharsis, consideradas como as três categorias básicas da experiência estética, não devem ser entendidas, hierarquicamente, como uma articulação de planos, mas como uma relação

de funções independentes: nós não podemos fazer retroagir umas às outras, mas elas sim podem estabelecer entre

si uma relação de causas" (JAUSS, 1986, p. 77)

8. "No ato estético o sujeito desfruta sempre de algo mais que de si mesmo; se sente na apropriação de uma experiência de sentido do mundo, que tanto pode descortinar sua própria atividade produtora como a integração de uma experiência de outrem, e passível de ser confirmada pela anuência de um terceiro. $\mathrm{O}$ prazer estético, que se desenrola no movimento pendular existente entre contemplação não interessada e participação experimentadora, é uma forma de experimentar-se ele mesmo nessa capacidade de ser outro, que o comportamento estético nos oferece"

Cadernos de Arguitetura e Utrbanismo, v.17, n.21, 2 sem. 2010 do relativismo", o foco estava na filosofia sensualista, e tomava o psicologismo empírico como base do prazer estético e da crítica de arte. Entretanto, a importância das sensações para a teoria da arquitetura declinou ao longo do século XIX devido à predominância do pensamento racionalista, expresso sobretudo pela arquitetura habitacional da primeira metade do século $X X$, na qual se pensou um edifício padronizado e produzido em série para um determinado tipo de usuário. ${ }^{5}$ Desde então, as questões concernentes à recepção de edifícios e lugares têm sido abordadas segundo modos que subestimam a complexidade dessa matéria, embora, de outro lado, os estudos urbanos cada vez mais se dediquem a compreender a experiência das pessoas comuns nos centros urbanos, isto é, a entender a vida de homens e mulheres vivendo em assentamentos urbanos adensados desde que a cidade industrial apareceu, com seu crescimento explosivo e suas transformações estruturais. ${ }^{6}$

A busca da legalidade de uma experiência estética própria à arquitetura pode reiniciar-se pela afirmativa de Hans Robert Jauss de que, na experiência estética, produção e recepção estão em permanente tensão dialética (JAUSS, 1986, p. 32). Isso se dá porque, para Jauss, a fruição é um parâmetro incontornável da estética, no qual compreender a obra moderna converte-se de transcrição de um sentido previamente elaborado para a instância da construção do sentido (CLAUDE, 1991, p. 131-147), mas só garantida na comunicabilidade que se estabelece entre obra e espectador; em outras palavras, quando o receptor executa o que a obra insinua. Produção e recepção são estruturas abertas onde se produz um sentido que, de início, não está revelado, mas se concretiza na sequência de recepções sucessivas ou no encadeamento de uma pergunta e uma resposta. A experiência estética se realiza quando o espectador adota uma atitude ante o efeito estético da obra em si mesmo; quando é capaz de compreendê-la com prazer e desfrutá-la compreendendo-a. Ou seja, fruição e criação são, de algum modo, atitudes intercambiáveis; ${ }^{7}$ e é nessa acepção de experiência estética que posso falar de uma complexidade que, almejada para a recepção do espaço, já está posta na criação do objeto arquitetônico. A experiência estética demanda tanto um artista como um espectador capaz de estabelecer uma atividade imaginativa, investigativa e fundadora de significados. ${ }^{8}$

Finalmente, em relação à delimitação da experiência estética é também elucidativo considerar aqui a modalidade do juízo que dela decorre. Um juízo estético, aquilo que afirmo acerca de um objeto, depende da circunstância em que o encontro e é sempre uma atividade por concluir: concorrem para o julgamento meu atos - investidos de emoção -, minha imaginação e a moldura na qual o objeto chega até mim. Afirma Wolfgang Iser que o estético "orquestra esse entrelaçamento de disposições humanas com objetos, mediante a conversão dos objetos desfamiliarizados em uma mola mestra para continuadamente ativar a interpenetração dos sentidos, de modo a dar surgimento a infinitas novas configurações, enquanto o forjamento dos objetos tira seus moldes dos sentidos" (ISER, 2001). Iser cita uma carta de Goethe a Rochlitz, onde se lê: "Há três tipos de leitor: o que desfruta sem ajuizar; aquele que sem desfrutar, ajuíza e outro intermediário, que ajuíza desfrutando e desfruta ajuizando; este é, de verdade, 
9. Como afirma Gumbrecht, na conferência do seminário "Comunicação e experiência estética".

10. Benedito Nunes. Notas de Aula, 1994.

11. “Die taktile Rezet des circunstanpetion erfolgt nicht sowohl auf dem Wege der Aufmersamkeit als auf dem der Gewohnheit. Der Architektur gegenüber bestimmt diese letztere weitgehend sogar die optische Rezeption. Auch sie findet ursprünglich viel weniger in einem gespannten

Aufmerken als in einem beiläuufigen Bemerken statt." In: Benjamin, Walter.GS I.2, (431-508),

Cadernos de Arquitetura e Urbanismo, v.17, n.21, 20 sem. 2010 o que reproduz uma obra de arte convertendo-a em algo novo" (GOETHE. Carta a J. F. Rochlitz, 13/6/1819, WA IV, tomo 3, p.178 apud (SER).

O estético implica uma ampliação e uma intensificação da percepção sensorial graças a um envolvimento direto ou intuitivo com um objeto, que minora o raciocínio analítico, de inferências, de classificação conceitual. Não se julga esteticamente a não ser na ausência de um critério fixo, ${ }^{9}$ exatamente porque a atenção estética é da ordem de dirigir-me a um objeto de tal modo que posso examiná-lo e, entretanto, não posso resumi-lo (HUGHES, 1999, p. 138). Ao contrário, o julgamento estético é devedor de um "comportamento que procura agir experienciando relativamente ao mundo de sua experiência". Fiona Hughes afirma que a atenção estética "não se livra, não deseja uma conclusão" (HUGHES, 1999, p. 135-138). Um objeto chama minha atenção e me leva a examiná-lo. Posso dissecá-lo, mas não resumi-lo, pois o objeto me toma num intercâmbio íntimo. $O$ ato de interpretar enreda o intérprete, é um ato prolongado indefinidamente à falta de um fundamento último. ${ }^{10}$ Assim, segundo Benedito Nunes, experimentar esteticamente significa engajar-se numa exploração imaginativa das coisas (HUGHES, 1999, p. 138). Muitas vezes é uma experiência de destaque na vida de alguém. Outras vezes, um deslumbramento. Noutras tantas, um episódio quase inteiramente imerso nos ritmos do seu dia. De qualquer maneira, condição do estético contemporâneo é a participação. Em meio a diversas formas da sensibilidade, não pode haver experiência estética sem que gente e coisas, ou, se quisermos, gente e situações se deixem misturar.

\section{Arquitetura urbana Situações}

Can there anything like an 'everyday architecture' similar to the notion of 'everyday life'? (...) Perhaps the best answer is given by Jun, the Japanese tourist who appears in Jim Jarmusch's 1989 film Mistery Train. Jun photographs only the interiors of the motel rooms in which he sleeps during his tour of the United States. Asked why he takes pictures of this kind of banal, even trivial, material, rather than the cities, monuments, and landscapes he visits, he answers that he photographs what he would easily forget: those other things are in my memory. The hotel rooms and the airports are the things I will forget. (TEYSSOT, 1993, p.153).

Ainda no ensaio sobre a obra de arte, Benjamin conclui que, "no que diz respeito à arquitetura, o hábito determina em grande medida a própria recepção ótica. Também ela, de início, se realiza mais sob a forma de uma observação casual que de uma atenção concentrada".11 Temos então a arquitetura referida aos seguintes domínios: por um lado, é obra de arte percebida distraidamente; por outro, é obra percebida a partir das determinações do hábito. Como hipótese, sustento que, graças a essa dupla inervação, distração e hábito, a experiência da arquitetura deve muito à experiência estética do cotidiano, não podendo, portanto, ser coberta em toda a sua dimensão pelo domínio da arte. 
12. "Architecture is defined by the actions it witnesses as much as by the enclosure of it walls" (TSCHUMI, 1994).
Pensar o cotidiano enquanto conceito implica problematizar o que Walter Benjamin chamou de "o menos idealista dos objetos" - a grande cidade em sua tessitura, isto é, considerar a vida urbana nas metrópoles, tratando dos desdobramentos da vida diária causados por ações dos habitantes e não somente pela forma durável de edifícios. Como afirma Bernard Tschumi, "a arquitetura tanto é definida pelas ações que ela testemunha quanto pelo invólucro de suas paredes."12 Uma vez que investigarei na arquitetura o que justamente excede o artístico e, entretanto, reside no estético, parto de uma definição dada por Maurice Blanchot, para quem o cotidiano "não está no lar, em nossas moradias; não está nos escritórios ou igrejas, menos ainda nas bibliotecas ou museus. Ele está na rua - se estiver em algum lugar. (...) A rua (...) tem o caráter paradoxal de ter mais importância que os lugares que ela conecta, mais realidade que as coisas que ela reflete" (BLANCHOT, 1987, p. 17).

A rua retira da obscuridade o que está escondido, torna público o que aconteceu em segredo fora dali - a rua deforma o acontecimento, dando à contextura social a forma do cotidiano. Segundo Blanchot,

O cotidiano é o suspeito e o oblíquo que sempre escapa à definição da lei. (...) O cotidiano é uma categoria, uma utopia e uma ideia, sem a qual ninguém sabe como alcançar o que se esconde no presente ou o futuro a ser descoberto (...). Ele escapa. Ele pertence à insignificância, e o insignificante não tem verdade, não tem realidade ou segredo, mas talvez seja também o lugar de toda significação possível (...). Ele é o desapercebido (...), isto é, [está] incluído numa visão panorâmica (genérica demais para captá-lo); mas, tratado de outro modo, o cotidiano é o que nunca vemos à primeira vista, apenas se olhamos de novo e mais uma vez, já o tendo visto desde sempre, na ilusão que o constitui. (...) Não há como não perdê-lo se por meio dele buscamos conhecimento, dado que pertence a uma região em que nada há para conhecer; mesmo antes de toda e qualquer relação, ele já está dito, mesmo se permanece não formulado. (BLANCHOT, 1987, p. 13-15)

Um conceito de vida cotidiana designa uma tentativa: só pode descrever um território aberto e irregular, talvez inexato, mas necessário, pois somente sua delimitação permite explorar diferenças e particularidades que demarcam o uso dos espaços, dando aos lugares o que pode ser denominado seu relevo originário, isto é, o uso que se confirma num espectro de possibilidades funcionais e que deixa traços na superfície das formas. Com o que, então, o objeto deste trabalho não são os edifícios tomados exclusivamente em suas formas, mas em determinadas estratégias cotidianas de uso da arquitetura em âmbito urbano, as quais se revelam importantes para uma discussão da dupla recepção da obra arquitetônica, ou seja, recepção por meios táteis e por meios óticos.

Chamo a tal objeto "arquitetura urbana", a qual, em suas raízes, designa uma particular experiência do espaço e do tempo que está além do olhar superficial, desenhada no modo de olhar "à segunda vista" de que falava Blanchot ao definir o cotidiano. É preciso desacelerar para perceber uma cidade em seus humores cambiáveis, 
13. Retomo aqui o sentido que Gadamer confere aos termos em sua hermenêutica da arte, referindo-se ao significado de uma obra que é determinado a partir da situação na qual esta se faça apresentar (Cf. GADAMER, 1960, p. 197). Para o filósofo, execução

é o que emerge da obra a cada novo encontro (cada ocasião) e que entretanto faz com que a obra seja sempre a mesma - a ocasião revela da obra o que Ihe é próprio. "É a obra mesma aquela que pode responder a cada ocasião em virtude da sua capacidade de falar" (Cf. GADAMER, 1960, p. 592). Gadamer se pergunta sobre o que é propriamente a execução e conclui: "Como começa, acaba, quanto tempo dura, como alguém

a alcança e como se chega ao final, permanecendo, não obstante, em algum

lugar, e podendo voltar a surgir. Uma coisa assim não a perguntamos. Isso é o que aprendemos precisamente na energeia de Aristóteles, esquecendo assim o perguntar. Certamente, é um

'momento', mas um momento que ninguém mede" (Cf. GADAMER, 1998,

p. 279-307)

Cadernos de Arquitetura e Urbanismo, vil7, n.21, $2^{2}$ sem. 2010 só assim se pode reparar nas árvores nuas sorvendo a luz nas manhãs ainda geladas de um começo de primavera, nos edifícios desabitados à margem de avenidas rápidas, parecendo ainda mais desolados sob o mormaço do verão, ou nas ruas se enchendo de gente e promessas com o nascer do dia. É quando a cidade dá-se como acontecimento, pondo em curso uma descrição fenomênica da vida urbana, que pressupõe encontros, confronto das diferenças, conhecimentos e reconhecimentos recíprocos. Lefebvre chamava à vida urbana "morfologia sensível e social da cidade":

A cidade depende também, e não menos essencialmente, das relações de imediatez, das relações diretas entre as pessoas e os grupos que compõem a sociedade (famílias, corpos organizados, profissões e corporações etc.) (...) Ela se situa num meio termo, a meio caminho entre aquilo que se chama de ordem próxima (relações de indivíduos em grupos mais ou menos amplos, mais ou menos organizados e estruturados, relações desses grupos entre eles) e a ordem distante, a ordem da sociedade, regida por grandes e poderosas instituições (Igreja, Estado). Abstrata, formal, suprassensível e transcendente na aparência, não é concebida fora das ideologias. Comporta princípios morais e jurídicos. Esta ordem distante se projeta na realidade prático-sensível. Torna-se visível ao inscrever-se nela. Na ordem próxima, e através dessa ordem, ela persuade (...). Ela se torna evidente através e na imediatez. A cidade é uma mediação entre as mediações. Contendo a ordem próxima, ela a mantém; sustenta relações de produção e de propriedade; é o local de sua reprodução. Contida na ordem distante, ela se sustenta; encarna-a; projeta-a sobre um terreno, (o lugar) e sobre um plano, o plano da vida imediata; a cidade inscreve essa ordem, prescreve-a, escreve-a. (LEFEBVRE, 1968, p. 46-59. Grifos nossos)

A ordenação espaçotemporal da arquitetura urbana tanto é linear como circular: são os tempos históricos, assim como o ciclo das estações de um ano; é a memória inscrita nas paredes dos edifícios, mas também os seus futuros não realizados, movendo-se furtivos e subterraneamente nos porões dos lugares ou guardados nos relatos dos habitantes. A metrópole é um amálgama de objetos gestados na cultura que a abriga; é mais que um conjunto de redes de transporte, edifícios, parques, rios. É mais que suas políticas públicas de segurança, serviços de saúde, sua legislação para o uso da terra, seus programas de habitação coletiva: a cidade é um contexto de significação e uma estrutura suportando o corpo de seus habitantes. Nesse sentido, a experiência do ambiente urbano dá-se para o indivíduo como nível primeiro de sua realidade material e cotidiana, aquele em que ele pode testar e reagir às mudanças à sua volta.

Pensar o cotidiano implica afastar-se de noções caras à arquitetura, tais como forma e estilo, as quais denotam a prevalência de um produto sobre o caráter de execução ou ocasionalidade ${ }^{13}$ concernente às obras arquitetônicas. Processos, imperfeições e ocupação de edifícios traduzem a ideia de vida cotidiana que está em jogo neste trabalho. Nela, a forma arquitetônica pode ser qualquer, pois interessam os resíduos e os vestígios deixados 
14. "The flâneur was a conscious observer for whom the word boredom had become meaningless: he animated all he saw; admired all the perceived. He strolled, observed, watched, espied." Rémy Saisselin In: MADSEN, 2002, p. 42.

15. Também diz Kracauer no texto sobre a agência de empregos: "Each typical space is brought into being by typical relationships that, without the distorting intervention of consciousness, express themselves on it. Everything that would otherwise be intentionally overlooked, contributes to its construction" (Cf. LEACH, 1999, p. 60).

Cadernos de Arquitetura e Utrbanismo, v.17, n.21, 2 sem. 2010 por quem a utiliza e ocupa. Trata-se de compreender a cidade pelo avesso do que foi desenhado pelo urbanismo moderno, descrevendo-a através das práticas sociais que se revelam sob as superfícies de concreto, asfalto, vidro e aço. A cidade não é um sistema: é um arranjo mental e social, o arranjo, segundo Lefebvre, "da simultaneidade, da reunião, da contingência, do encontro (ou antes, dos encontros). É uma qualidade que nasce de quantidades (espaços, objetos, produtos)" (LEFEBVRE, 1968, p. 81). Isto é o que Benjamin dizia sobre fazer botânica no asfalto, o modus operandi do flâneur, que, mais que simples caminhar, designa uma prática espacial urbana que é tentativa de examinar a cidade em detalhe de modo a encontrar seus segredos escondidos e rastrear suas histórias não de todo realizadas. Assim agirá também o teórico da arquitetura que assuma a tarefa de analisar a metrópole: somente um trabalho de detetive recolhe as imagens da cidade cunhadas nos vestígios do cotidiano. ${ }^{14}$

A tais imagens Siegfried Kracauer chamou de "expressões superficiais", que, pertencendo à esfera do inconsciente, permitem ver a substância das coisas; e, de modo reverso, qualquer conhecimento das coisas passa a depender da interpretação dessas expressões em nível de superfície, também denominadas "imagens espaciais" (KRACAUER, 1975, p. 75). Interlocutor de Benjamin, Kracauer afirmava que as imagens espaciais são os sonhos da sociedade: "Onde quer que os hieróglifos de qualquer imagem espacial sejam decifrados, ali se apresenta a base da realidade social."15 Assim, a compreensão da cidade depende diretamente da habilidade em decifrar as imagens de sonho que ela produz em suas contradições e contrastes, sua rudeza e esplendor, suas justaposições e simultaneidades.

$\mathrm{Na}$ desconsideração de tais imagens foi exatamente onde falhou o ideário do urbanismo funcionalista moderno, que, ainda que fundado sobre uma racionalidade organizadora e operacional, não possibilitou quantificar e planejar minuciosamente uma cidade. Há nela um sem-número de experiências sendo vividas, múltiplas relações de poder e formas de resistência - para que tudo possa ser captado pela norma. Ao contrário, a vida no espaço urbanizado dá-se no tecido de seus paradoxos, espaços a uma só vez contínuos e fragmentados, dos quais se constitui nossa percepção. Para a arquitetura urbana não há respostas simples, tampouco há significados únicos a serem ali depositados e retirados a bel-prazer de arquitetos, publicitários e planejadores. Vivemos a cidade constantemente pelo seu avesso, atravessando-a e sendo por ela atravessados, e isso é algo inquantificável. É um modo de experimentar o espaço necessariamente indiferente à quantidade, cuja análise deve se fazer do ponto de vista das práticas espaciais socialmente consolidadas, jamais tomadas exclusivamente segundo seu desenho e forma.

A entrada do cotidiano no pensamento e na consciência contemporâneos deu-se através da literatura, com autores bem conhecidos: Balzac, Flaubert, Zola, Broch, Joyce. Entretanto, somente depois do colapso que representou a segunda guerra mundial, mais exatamente a partir dos anos 1970, a análise do cotidiano ganha força no ambiente intelectual, em parte decorrente da incapacidade do capitalismo industrial em suas principais figurações (instituições políticas, poder corporativo, inovações tecnológicas, publicidade) em 
16. O cotidiano, por meio das domesticidades, aponta duas direções: de um lado pré-formas, rascunhos que expõem quanto do comportamento é governado pela convenção; de outro lado, relações entre viver e viver ao redor, entre forma positiva e forma negativa. Sobre o cotidiano e a vida doméstica, Alan Wexler diz, a partir da sua Crate House, estar "interessado no desconforto; tento fazer as pessoas pensarem duas vezes, recomeçar, voltar, olhar de perto. Perdemos de vista as coisas cotidianas, perdemos o tato." (...) "O que é que define uma cozinha? Que objetos escolhemos para cada função?

Que ações implicam esses objetos? Concebo cada container como se fosse um diorama de um museu de história natural; a almofada, a esponja, a lanterna, o sal. (...) São essas coisas que isolo, transformo em escultura, uso como se fosse teatro".

Cadernos de Arquitetura e Uthanismo, v.17, n.21, 2" sem. 2010 conferir maior liberdade à massa da população vivendo sob a norma do capitalismo, em parte graças ao intenso debate acerca das liberdades civis em torno de 1968. A atenção deslocou-se para a interação humana na microescala de ações das pessoas comuns; o foco das análises sociais voltou-se para a experiência qualitativa das pessoas comuns que formam a multidão sem nome ou rosto. Essa abordagem, crítica das concepções liberais de modernidade, concebe os movimentos históricos duradouros como práticas dinâmicas nas quais as pessoas comuns contribuem mais que as estruturas impessoais ou forças impostas pelo Estado ou por um mercado abstratos. O objetivo dos estudos do cotidiano, que utilizam ferramentas derivadas da antropologia social e cultural, é, principalmente, capturar a vida individual na rede complexa das questões sociais e políticas, reconstruindo e explicando as relações recíprocas entre ações e experiências individuais, por um lado, e a vida material, os processos e as instituições, por outro. O mundo cotidiano, pré-conceitual, demarca uma experiência, cujo modo é subjetivo-relativo, conjugada "aos gestos repetidos, às histórias silenciosas e como que esquecidas dos homens, às realidades de longa duração cujo peso foi imenso e o ruído, imperceptível."

A rigor, o termo "vida cotidiana" surge do movimento de transformação das relações sociais, a partir do século XVIII. Já ali o conceito receberia alguns dos seus contornos atuais, sobretudo correlativamente aos espaços arquitetônicos, pois é também a partir do século XVIII que podemos designar algo como uma arquitetura de interiores, isto é, desenho e configuração específicos para os lugares de moradia. Quando a esfera do privado emerge no Ocidente, denotando a separação dos âmbitos de vida social e privada, isso vem ao encontro da autonomia da vida familiar e do espaço doméstico como esfera da reprodução da existência. A vida social, ao contrário, passaria a significar a face pública da vida, isto é, a esfera dos espaços de produção das condições materiais de sobrevivência.

Trazer a categoria da vida cotidiana à análise da arquitetura urbana expõe o desencantamento do racionalismo, e representa uma tentativa de pensar uma arquitetura capaz de resistir ao paradigma de consumo e conforto a qualquer preço, ou que possa dar conta de estratégias anônimas de apropriação espacial, precisamente aquelas que - como nos lembra Henri Lefebvre - entregam ao cotidiano a obra inacabada, "a atividade criadora inerente a ele" (LEFEBVRE, 1968, p. 22), em que "há fissuras, mas não princípios; descontinuidades, mas não fins. Intervalos, mas sem atos nem acontecimentos propriamente ditos" (LEFEBVRE, 1968, p. 19). Para Walter Benjamin e para Henri Lefebvre, a experiência do cotidiano se oferece como problema; para ambos essa é a forma da experiência vivida que mais diretamente envolve a habilidade para tornar as coisas estranhas. Considerada sob esse aspecto crucial, a vida cotidiana permite a Benjamin (teoria da montagem) e Lefebvre (teoria dos momentos) formularem cada um sua teoria da experiência estética a partir da configuração moderna do cotidiano esboçada no surrealismo, quais sejam as justaposições surpreendentes e o resgate do cotidiano aos hábitos convencionais. Em outras palavras, o cotidiano sobre o qual se debruçam esses autores é o da vida urbana experimentada em seu equívoco, ambiguidade e instabilidade. ${ }^{16}$ 
17. Os seguintes textos de Husserl fundamentam minha abordagem:

"Philosophy in the crisis of European mankind" (Conferência de Viena, 7-10 maio 1935); "The crisis of European sciences and transcendental phenomenology", 1937 (parte III, Seção

A: "The way into phenomenological transcendental philosophy by inquiring back from the pregiven life-world", §28-

55); "The origin of Geometry", 1936;

"The life-world and the world of science",

1937; "Objectivity and the world of experience", 1936

18. "With the concept of 'horizon' borrowed from the perceptual experience of a landscape, what kind of 'horizon' would 'Times Square'/or similar urban 'landscapes' then provide?" (MADSEN, 2002, p. 1-41).

19. Me lembro aqui de uma fala de Neil Leach, dedicada à memória de 9/11/2001: "The potential of architecture to convey a level of symbolic meaning beyond the materiality of its fabric".

Cadernos de Arquitetura e Utbanismo, v.17, n.21, 2 sem. 2010
Ora, desempenhar tal análise da vida urbana significa lidar no domínio de uma "vaga racionalidade", que é da ordem do mundo da vida, ou seja, na vida real com suas resistências e contradições, sua comunicação difícil e distorcida. A ideia de uma "razão da vida real" fundou duas teorias filosóficas que devem ser lembradas aqui. Em primeiro lugar, o conceito fenomenológico de Lebenswelt (mundo da vida), no qual a racionalidade se apresenta de modo difuso, a que Edmund Husserl chamou verdade cotidiana, isto é, verdade prática e situacional, relativa, "mas exata no que a práxis demanda."17 Qualquer experiência desenrolada no cotidiano pressupõe um horizonte, ou seja, o conjunto das expectativas que cada usuário traz consigo, aquilo que no conhecimento individual temático é percebido ou antecipado atematicamente. Toda experiência tem a estrutura do horizonte, na medida em que é determinada por um saber prévio de novos conteúdos que ainda não chegaram a ser dados tematicamente. $O$ horizonte é um conhecimento prévio não totalmente determinado quanto a seu conteúdo, nem totalmente vazio - um desconhecimento que é, ao mesmo tempo, um modo de conhecimento.

Que sentido pode ter o conceito husserliano de "horizonte" 18 no contexto da paisagem urbana? O mundo da vida é um conceito desenvolvido para abarcar o horizonte de compreensão do cotidiano. Ao se considerar a vida cotidiana como medium da experiência arquitetônica, é possível estabelecer, como hipótese, um paralelo entre a forma do hábito em Walter Benjamin e aquela que nos apresenta a fenomenologia de Husserl, na qual o hábito está sempre vinculado ao mundo da vida, demarcando o terreno das ações humanas. O hábito pode ser pensado, em Husserl, como elemento que estabelece a referência espacial, antecedendo a reflexão. Para além da noção de que a vida cotidiana esgota-se na rotina administrada de indivíduos frágeis, sempre dominados pela experiência inescapável da repetição, Husserl considera o cotidiano para além dessa posição, uma vez que é ao mesmo tempo prático e simbólico, real, mas também imaginário e, por isso, evidente e contraditório. Próximo e distante, mas jamais direto, pelo contrário, revela-se precário e opaco. É preciso tomar a vida cotidiana de modo a transpor suas hierarquias e formas de controle, e, assim, avançar através da opacidade. Se cada momento da experiência de um lugar arquitetônico resultar em apreensões diversas, articuladas entre si, seja pela reversão ou confirmação das expectativas, a recepção desses lugares no mundo da vida pode se tornar fértil e não somente repetitiva. Cada momento de experimentação dos espaços, desde que articulados, pode criar uma combinação intrínseca de perspectivas diferenciadas, seja de horizontes de memórias, de modificações presentes ou de futuras expectativas.

O mundo da vida é um conjunto de fenômenos linguísticos, de padrões discursivos e de instituições sociais, tudo isso aliado a uma frouxa, mas onipresente regulação dos comportamentos. As instituições operam em estruturas físicas, edifícios e outras configurações de ambientes construídos. ${ }^{19}$ Mas considerar a arquitetura não como espetáculo ou vertigem de profusão de imagens, e sim como lugar de acomodação do olhar e do corpo pela familiaridade adquirida, implica atribuir à obra a tarefa de indagar o usuário, expô-lo ao impasse de não saber como proceder, mas 
20. A Carta de Atenas é um documento publicado em 1941 por Le Corbusier, redigido a partir das discussões ocorridas na quarta conferência do CIAM (Congresso Internacional de Arquitetura Moderna), iniciado em 29 de julho de 1933, a bordo do Patris II, partindo de Marselha, e concluído dias depois em Atenas, prestigiado pelo apoio do governo grego. A Carta definiu o que é o urbanismo racionalista moderno, também denominado urbanismo

funcionalista, traçando diretrizes e fórmulas que, segundo seus autores, seriam aplicáveis internacionalmente.

A Carta considerava a cidade como um organismo a ser planejado de modo funcional e central, na qual as necessidades do homem devem ser claramente colocadas e resolvidas. Os seus fundamentos defendiam a elaboração de um modelo de cidade infinitamente reprodutível, organizada para satisfazer quatro necessidades básicas; as chaves do urbanismo estão nas quatro funções: habitar, trabalhar, recrear-se (nas horas livres), circular. Ali os habitantes eram vistos segundo constantes biopsicológicas e para eles propunha-se um espaço cujo tratamento homogêneo não incorporava análises de diferenças de classe e desconsiderava as diversas condições e contradições de apropriação do espaço presentes em nível intraurbano.

Cadernos de Arquitetura e Urbanismo, v.17, n.21, 20 sem. 2010 querer desvendar. A razão da arquitetura está, então, na sua imediatez, sua capacidade para articular a vida em sua circunstância (PÉREZ-GÓMEZ, 1999, p. 20).

No que concerne à arquitetura da cidade grande e moderna, escrever sua história do ponto de vista do cotidiano exige fazer a crítica da quantificação das coisas configurada nos ideais racionalistas da planificação e da tipologia que tomaram o lugar da experiência concreta. Implícita na ideia funcionalista de que o arquiteto é o único habilitado em prever o uso de um edifício está a presença de um usuário controlável e passivo, incapaz de transformar o uso, o espaço e a sua significação para a própria vida.

A arquitetura funcionalista produziu um tipo de espaço que é justamente o resultado do raciocínio que se abstrai do mundo e da vida cotidianos. Tal raciocínio, afeito ao mundo técnico-científico, explica-se também para o planejamento dos espaços, tal como foi concebido sob a rubrica do movimento moderno. $\mathrm{O}$ arquiteto do movimento moderno, para seus desenhos, apropriou-se de modelos reducionistas de experiências, que não raro implicavam uma formalização da realidade, uma quantificação das coisas, o que ocupava o lugar da experiência concreta - separando coisas do seu entorno vital, no qual o conhecimento é de caráter pessoal e vem dado na experiência cotidiana. O resultado desse procedimento - cuja vigência fica estabelecida - pelo menos teoricamente no ideário arquitetônico a partir da redação da Carta de Atenas ${ }^{20}$ é bem conhecido. O texto que se segue é evidentemente uma resposta àquela declaração de princípios da arquitetura moderna:

À nossa frente, como um espetáculo, (...) os elementos da vida social e do urbano, dissociados, inertes. (...) Eis uma vida cotidiana bem decupada em fragmentos: trabaIho, transportes, vida privada, lazeres. A separação analítica os isolou como ingredientes e elementos químicos, como matérias brutas, quando na verdade resultam de uma longa história e implicam uma apropriação de materialidade. Ainda não acabou. Eis o ser humano desmembrado, dissociado. Eis os sentidos, o olfato, o paladar, a visão, o tato, a audição, uns atrofiados, outros hipertrofiados. (LEFEBVRE, 1968, p. 97)

Ora, a matéria da arquitetura urbana - a cidade vivida cotidianamente, como nos recordou Lefebvre - não é uma linguagem, mas uma prática. De um ponto de vista fenomenológico, isso significa que ela deve ser compreendida na circunstância que rodeia o sujeito (Umwelt), captada no horizonte de sua ação (horizonte é "uma totalidade percebida de modo não explícito", pressuposta, mesmo quando não tematizada - e que, não obstante, condiciona e determina o sentido de cada coisa nela demarcada; horizonte é demarcação de possibilidades). O mundo da vida, posto em relação com qualquer atividade do homem, atua como suporte subjetivo de toda objetividade. Se "o mundo da vida é uma sedimentação histórica produzida pelos homens enquanto pessoas e assumida pela subjetividade individual" (GÓMEZ-HERAS, 1989, p. 249), pautar novamente o cotidiano implica assumir que a cidade experimentada não pode ser descrita em sua totalidade nos termos dos urbanistas e dos planejadores, tampouco nos termos dos geógrafos. Ninguém tem, para dizer as 
palavras de Lefebvre, "os poderes de um taumaturgo" (LEFEBVRE, 1968, p. 107). Antes, a cidade é um conjunto de relações sociais, portanto deve ser analisada como um ponto nevrálgico da experiência intersubjetiva, como o local híbrido e heterogêneo da representação de um si e de outrem. Nenhum profissional cria as relações sociais:

Apenas a vida social (a práxis) na sua capacidade global possui tais poderes (...). Os arquitetos parecem ter estabelecido e dogmatizado um conjunto de significações mal explicitado como tal e que aparece através de diversos vocábulos - 'função', 'forma', 'estrutura', ou antes, funcionalismo, formalismo, estruturalismo. Elaboram-no não a partir de significações percebidas e vividas por aqueles que habitam, mas a partir do fato de habitar, por eles interpretado. Esse conjunto é verbal e discursivo, (...) é grafismo e visualização. (LEFEBVRE, 1968, p. 109)

Para trazer ao primeiro plano a interrogação sobre o uso e os usuários, é necessário que nos detenhamos nesse espaço híbrido, ao mesmo tempo material (dos objetos), físico (do ambiente) e corpóreo, que constitui o âmbito da experiência sensível em que as pessoas habitam, vivem e agem, reunindo o que o funcionalismo dissociou, num arranjo "da simultaneidade e dos encontros", como o chamou Lefebvre. Para compreender o uso da arquitetura, é preciso mergulhar na conjunção do mundo da vida com o horizonte da cultura, o mundo da práxis; isto é, para responder à pergunta acerca de como usuários lidam com lugares, é preciso pensar nos grupos de habitantes que modelam o espaço urbano com seus modos de viver - em nível das relações imediatas, pessoais e interpessoais (família, vizinhança, profissão, corporações, divisão do trabalho entre as profissões). Tais comunidades urbanas é que efetivam os processos que constroem uma cidade, nela se introduzindo, dela se apropriando, inventando e atribuindo a si novos ritmos. São esses habitantes urbanos que "inovam no modo de viver, de ter uma família; (...) essas transformações da vida cotidiana modificaram a realidade urbana, não sem tirar dela suas motivações. A cidade foi ao mesmo tempo o local e o meio, o teatro e a arena dessas interações complexas" (LEFEBVRE, 1968, p. 52).

Viver numa cidade envolve uma experiência das instituições sociais, das estruturas materiais, dos meios de transporte e comunicação; implica adquirir habilidades para interagir com os mais variados fenômenos, mover-se num mundo cada vez mais plástico, e aprender a lidar com conflitos - significa a aquisição de consciência. Viver num ambiente urbano, em cidades que crescem e se transformam de modo extremamente rápido, onde miIhões e milhões encontraram seu próprio mundo da vida, que é radicalmente diferente das gerações que os precederam, é trafegar entre a tradição e o horizonte posto por seus novos habitats, suas novas situações.

Se releio o pequeno trecho de Georges Teyssot que serve de epígrafe a este item, penso em como a representação das coisas que preenchem o espaço humano por meio de um aparato pode produzir inesperadamente uma intensificação da experiência arquitetônica. Naquele caso, a câmera se incumbiria de dar relevo 
ao que ficou mergulhado na inconsciência - na penumbra do momento vivido. O aparato fotográfico permite guardar o avesso da experiência, como se a memória, graças à câmera, pudesse expor suas camadas. Aquilo de que você se lembra sozinho é sua experiência forte; o que a máquina guarda para lhe fazer lembrar, sua experiência fraca - mas ambas somam-se, remetem uma à outra, a cada vez que a lembrança daquele lugar estiver em pauta na sua existência.

\section{Reflexionsmedium de Walter Benjamin}

Ao abordar o mundo da vida, faço-o a partir de uma atitude referencial, que permite questioná-lo em sua realidade; isto é, atitude que o indaga a respeito do como dos modos subjetivos de doação do mundo da vida e de seus objetos. A fenomenologia, nesse sentido, opera submetendo todo fenômeno a "variações transcendentais para ver qual núcleo essencial resiste", para recolher o que se destaca e se revela através desse núcleo de significação essencial, "constituindo os possíveis que ele articulará em produções doravante asseguradas de sua validade e de sua legitimidade" (HUCHET, 2005, p. 169-234). Se analisamos o fenômeno-arquitetura desde essa matriz conceitual, percebemos que sua principal articulação dá-se no solo da práxis, na atividade pela qual os seres humanos transformam a realidade e a si próprios, revelando-se um fenômeno de tal complexidade que em muito excede a atitude ingênua e espontânea de apenas conviver no mundo, à qual muitas vezes se associa erroneamente a fenomenologia. Antes, na análise da arquitetura, a teoria fenomenológica pauta o início do caminho, por assim dizer, na medida em que descreve as variáveis em jogo nesse fenômeno, indicando direções de sua investigação, como a que se estabelece aqui, a saber, uma conjugação entre a fenomenologia e o materialismo.

O desenvolvimento do capitalismo evidenciou que "os novos temas que se propagam à cultura arquitetônica estão, paradoxalmente, aquém e além da arquitetura" (TAFURI, 1968, p. 10), posições tais que só podem ser elucidadas numa abordagem materialista dos objetos arquitetônicos e do uso destes pelos habitantes.

Em 1844, Karl Marx denominou materialismo àquele pensamento que se ocupa dos homens efetivamente ativos e toma como ponto de partida "o processo efetivo da vida deles", de tal forma que o foco da reflexão filosófica fosse redirecionado para os problemas concretos concernentes ao processo da vida humana, "empiricamente constatável e ligado a pressupostos materiais", buscando os caminhos para solucioná-los na situação histórica específica - meio concreto - que os gerou.

Inteiramente em oposição à filosofia alemã, que desce do céu para a terra, aqui se sobe da terra para o céu. Em outras palavras, não se parte do que os homens dizem, pensam, imaginam, se representam; também não de homens ditos, pensados, imaginados, representados, para daí chegar aos homens de carne e osso; parte-se de homens efetivamente ativos e a partir do processo efetivo de vida deles (MARX, 2004, p. 193). 
21. WOLLEN, Peter. Bitter Victory. The arts and the politics of the International Situationist. Wollen diz que esse é um livro fermentado pelas lutas revolucionárias do começo do século XX. Assim como os textos de Korsch, integra a categoria dos livros-produto do "fermento revolucionário", todos representantes da primeira fase do marxismo ocidental.
O objetivo de Marx era ultrapassar aquela tradição filosófica que resultava em distanciamento do mundo prosaico e cotidiano; nesse sentido, o materialismo fundava-se no princípio da prática, para superar tal contemplação distanciada. "O princípio da prática, enquanto princípio de transformação da realidade, deve então ser talhado na medida do substrato material e concreto da ação, para poder agir sobre ele quando entrar em vigor" (LUKÁCS, 2003, p. 267). Georg Lukács, em História e consciência de classe, diz que somente a ação consciente - decorrente do princípio da prática - pode valer como atividade, num mundo em que, como consequência do "desenvolvimento da sociedade burguesa, todos os problemas do ser social deixam de transcender o homem e se manifestam como produtos da atividade humana."21 Ora, trata-se no materialismo, portanto, do redimensionamento do conceito de homem - o burguês, egoísta, individual e artificialmente isolado pelo capitalismo, cuja consciência, "enquanto fonte de sua atividade e de seu conhecimento, apresenta-se como sendo isolada e individual, nos moldes de Robinson Crusoe". Não é a consciência que determina a vida, mas sim a vida que determina a consciência, observava Marx (2004, p. 193). Uma vez isolado e egoísta, o indivíduo que vive na era do capital vê suprimido o caráter de atividade da ação, sobretudo da ação social; a prática representa a possibilidade de reverter tal estado de coisas, pois é o que orienta "para o que há de qualitativamente único, para o conteúdo e o substrato material de cada objeto" (LUKÁCS, 2003).

O princípio da prática implica a diversidade de atitudes do sujeito, o qual compreende o mundo em que vive percebendo complexidades, diferenças, conflitos, contradições. Assim, tem-se que a compreensão da realidade por um indivíduo é um processo duplamente determinado, pela história e pela práxis. Henri Lefebvre elabora uma conjugação consistente dos enfoques da fenomenologia e do materialismo, ao descrever essa percepção que é também compreensão.

O que os psicólogos chamam 'percepção' ou o 'mundo percebido' é, na realidade, o produto da ação humana em nível social e histórico. A atividade que cria o mundo exterior e sua forma fenomenal, não teórica e formal, mas prática e concreta. Ferramentas práticas, não simplesmente conceitos, são os meios pelos quais o homem social conforma o mundo percebido. Ao lembrar os processos do conhecimento por meio dos quais compreendemos tal 'mundo', ele se aparta da imensidão da natureza e desenha-se coerente e humano. Esses processos não são categorias a priori ou intenções subjetivas; eles são nossos sentidos. Mas nossos sentidos têm sido transformados pela ação. Capaz de compreender e organizar determinadas totalidades, determinadas formas, o olho humano não é tão-somente o órgão natural de visão de um vertebrado superior, de uma figura solitária perdida no mundo natural, de um homem primitivo ou de uma criança. Logo, o 'mundo' é o espelho do homem porque o homem o faz assim: é a tarefa da sua vida cotidiana e prática. Mas não é seu 'espelho', de um modo passivo (LEFEBVRE, 1991, p. 163).

Para alcançar o "aquém e além" da arquitetura de que falava acima, valho-me da força especulativa dos textos de Benjamin, cuja filosofia, como disse José Guilherme Merquior, é algo que 
22. Com a sua leitura de LUKÁCS, G. História e consciência de classe, em 1924.

23. Como mostra Willi Bolle em valoroso artigo, "a grande cidade contemporânea marcou a forma e o estilo da escrita benjaminiana da história" (BOLLE, 1999, p. 89-112).

24. "A crítica inclui o conhecimento de seu objeto (...); exige uma caracterização da teoria do conhecimento do objeto que está em sua base. (...) A teoria do conhecimento do objeto é determinada pelo desdobramento do conceito de reflexão em seu significado para o objeto" (BENJAMIN, 2000, p. 61).

25. A função do maior criticismo não é, como frequentemente se pensa, instruir com os significados das descrições históricas ou educar através das comparações, mas conhecer por meio da imersão no objeto (BENJAMIN, 2000, p. 293).

Cadernos de Arquitetura e Urbanismo, vil7, n.21, $2^{2}$ sem. 2010 a fenomenologia jamais conseguiu ser: descritividade, é certo, mas primeiramente crítica (MERQUIOR, 1969, p. 114). Tomando como pressuposto essa particular conjunção de fenomenologia e materialismo, denominada descritividade crítica, remeto, então, meu argumento ao que Walter Benjamin chamou Reflexionsmedium, retomando o termo utilizado pelos românticos de Jena, para designar a "qualidade da obra de arte de proporcionar o conhecimento crítico" (BENJAMIN, 1993, p. 40).

"A intensificação da reflexão, antes, supera na coisa os limites entre ser conhecida através de si mesma e através de um outro; e, no medium de reflexão, a coisa e a essência cognoscente se interpenetram" (BENJAMIN, 1993, p. 64-65). Benjamin localiza os conceitos românticos de percepção, observação da natureza e de crítica de arte no contexto de uma teoria do conhecimento (GAGNEBIN, 1999, p. 71), mas é possível desdobrar essa teoria também no Trabalho das passagens. Desde o momento em que seu pensamento inflecte para o materialismo, ${ }^{22}$ Benjamin considera a metrópole um medium de reflexão, ${ }^{23}$ isto é, um meio de refletir sobre as contradições do capitalismo como um todo a partir de um pesar sobre a vida urbana em viés materialista. Em carta a Scholem, no momento em que retomava os estudos do Trabalho das passagens, para o texto que havia sido solicitado pelo Instituto de Genebra, ele escreveu:

\begin{abstract}
Encontrei-me realmente sozinho com meus estudos das 'passagens', o que aconteceu pela primeira vez em muitos anos. (...) Aqui o ponto central também será o desenvolvimento de um conceito clássico. [Se no livro sobre o barroco tratava-se do conceito de tragédial, aqui é o caráter de fetiche da mercadoria. Se o livro sobre o barroco mobilizou a própria teoria do conhecimento, o mesmo deveria acontecer no caso das 'passagens', pelo menos na mesma proporção. (SCHOLEM; BENJAMIN, 2004, p. 219. grifo nosso)
\end{abstract}

Toda crítica deve conter uma teoria do conhecimento daquele objeto que se critica, ${ }^{24}$ teoria essa que é o conceito de reflexão desdobrado para o objeto, aplicado a ele de tal forma que conhecer somente seja possível "por meio da imersão no objeto."25 Há uma reciprocidade entre a organização interna da obra e o movimento da crítica que se debruça sobre essa obra: "A crítica tem, afinal, muito pouco a ver com a subjetividade do gosto do crítico e tudo a ver com a organização inerente à própria obra" (GAGNEBIN, 1999, p. 68 e 73).

No Trabalho das passagens a cidade é objeto que deve ser criticado, o que implicava caracterizar a teoria que permite conhecê-lo, isto é, pensar a cidade a partir do conceito de reflexão relativo a ela. Não se faz a crítica da cidade grande oitocentista (a metrópole encarnada tanto em Paris como em Berlim) com explicações de significado de um ou outro arranjo formal, tampouco comparando-a a configurações urbanas passadas. Se criticar é fazer um "experimento na obra", refletindo para transformá-la, na cidade esse medium de pensar é mais que nunca necessário. Benjamin compreendeu de modo agudo a trama de muitos fios envolvendo esse objeto sobre o qual se debruçou: concentrar-se na cidade implica desdobrar seu lado avesso, conduzindo-a para fora de si, para "aquém e além", expondo suas relações com as 
26. "A crítica é então como que um experimento na obra de arte" (BENJAMIN, 2000, p. 74) demais obras e com os fenômenos históricos, pois a metrópole moderna é justamente o espaço da simultaneidade de tempos históricos diversos.

Buck-Morss assinala que Benjamin fazia um materialismo levado tão a sério que "os próprios fenômenos chegariam a falar" (BUCK-MORSS, 2002, p. 27). Na medida em que, para ele, crítica era um modo de refletir que transformava a forma, isso incluía descobrir e experimentar modos de expor a forma, ${ }^{26}$ dando voz a elementos componentes dos fenômenos antes silenciados, por exemplo, descrevendo os moradores de uma cidade grande. Esse misto de observação e experimento deixa-se ver em outra carta a Scholem, escrita a 12 de junho de 1938, na qual Benjamin especulava:

Ao me referir à experiência do moderno habitante das metrópoles, incluo diferentes aspectos. Por um lado, falo do cidadão moderno, entregue a um aparelho burocrático interminável, cuja função é comandada por instâncias que permanecem imprecisas para os próprios órgãos executivos, quem diria então para as pessoas a elas subordinadas (...). Por outro lado, quando falo do habitante moderno das grandes cidades refiro-me aos físicos contemporâneos (...) se é que um indivíduo deva ser confrontado com a realidade que se projeta como sendo a nossa, teoricamente, por exemplo, na física moderna e praticamente na técnica de guerra. Com isso quero dizer que essa realidade, praticamente, não é perceptível para o indivíduo, e que o mundo de K., tão alegre e povoado de anjos, é o complemento exato para uma época que se dispõe a aniquilar em grande escala os habitantes desse planeta. Só é de se esperar que as grandes massas façam essa experiência, que corresponde à de Kafka como pessoa particular, incidentalmente e por ocasião desse aniquilamento. (SCHOLEM; BENJAMIN, 2004, p. 303)

Benjamin evidenciava sua compreensão de que, no século $X X$, a arquitetura da metrópole faz o papel - análogo ao da arte - de transformar a consciência. Em parte isso se devia à tecnologia empregada nos edifícios, que operara uma significativa transformação física na cidade a partir de meados do século XIX. A arquitetura oitocentista, feita de ferro e vidro, era precursora de sua própria época - como tal, um ur-phenomenon da modernidade. Para "os sujeitos históricos da geração do próprio Benjamin" (BUCK-MORSS, 2002, p. 27) - herdeiros, em 1930, da cidade do século XIX - esse era um fato capaz de oferecer uma educação marxista-revolucionária, pois mostrava onde se dera a origem daquele estado de coisas então vivido.

Benjamin apontava a necessidade de tornar visível tal arquitetura (galerias, lojas de departamentos, pavilhões de exposição, mercados, estações de trem) - ou o seu resíduo anacrônico mostrando o quanto a forma transitória dessas construções era expressão adequada do século XIX, este, por sua vez, também um período de transição.

Imitações de cariátides gregas em colunas de ferro denunciavam que os novos materiais construtivos haviam chegado cedo demais. "No primeiro terço do século passado ninguém tinha ideia 
27. Benjamin, W. Gesammelte Schriften, Unter Mitwirkung von T.W.Adorno u. G.Scholem, hrsg.v. R.Tiedemann u. H. Schweppenhäuser, Frankfurt a.M., Suhrkamp Verlag, (Bde. I-VII). 1972-1989, p.218 [F3,2]

28. Benjamin cita giedio em diversas notas de seu trabalho sobre as passagens Ibidem. p.218 [F3,2]

29. a tecnologia construtiva em ferro continha, para Benjamin, muitas imagens de futuro não realizado. Ibidem. [K1a, 7]

30. todas as profissões em que a técnica redefinu o modo de criar. Ibidem. V K1a, 4.

31. "Toda arquitetura do século XIX propiciava morada para o sonho coletivo." Ibidem. "Os arquitetos são produtores da imaginação coletiva." BENJAMIN, Exposé de 1935.

32. BENJAMIN, Exposé de 1935.

Cadernos de Arquitetura e Urbanismo, v.17, n.21, $2^{0}$ sem. 2010 de como se devia construir com ferro e vidro."27 Para Siegfried Giedion, historiador da arquitetura que entusiasmava Benjamin, o problema foi resolvido desde então pelos "hangares e silos." 28 Benjamin acrescenta um comentário ao texto de Giedion, perguntando se seria adequado afirmar que "a construção desempenha no século XIX o papel do processo corpóreo em torno do qual se colocam as arquiteturas 'artísticas' como os sonhos em torno do arcabouço do processo fisiológico,"29 apoiando a necessidade de se "ocupar com essa matéria-prima, esses edifícios cinzas mercados cobertos, lojas de departamentos, exposições".30

A arquitetura de Paris deslumbrava a multidão, tomava-lhe todos os sentidos. O que os arquitetos haviam produzido ali eram não apenas edifícios, mas a "morada para o sonho coletivo".31 A crítica ao século XIX começava pelas formas arquitetônicas que expressaram os sonhos coletivos daquele século, no qual acontecera uma mistura singular de tendências individualistas (o eu, a nação, a arte) e elementos para uma configuração coletiva, elementos que estavam nos subterrâneos, mais exatamente nos domínios cotidianos da vida urbana. Benjamin entendia que a transformação da consciência operada por meio dos efeitos dessa arquitetura urbana era um dos fundamentos da dialética da mudança social. A metrópole, onde atuavam arquitetos - junto com "fotógrafos, artistas gráficos, desenhistas industriais, engenheiros" 32 -, exercia um papel decisivo na educação política. A grande cidade é o elemento da história materialista sobre a qual Benjamin - tributário de Marx - escreve, desencantando a nova natureza (industrial), livrando-a do feitiço do capitalismo. Benjamin, por meio de sua reflexão sobre a metrópole oitocentista, escreveu uma interpretação da modernidade como mundo de sonho do qual se deve despertar coletivamente para a conscientização revolucionária de classe.

Indústria e tecnologia promoveram uma tal ruptura no espaço urbano que ao habitante escapava qualquer nexo causal; só recebiam a mudança nos lugares e ritmos do seu próprio cotidiano. No século XIX, Paris e outras capitais da Europa estampavam o luxo e a promessa do desenvolvimento urbano. Benjamin, mesmo sabendo que Londres, do ponto de vista econômico, era a sede da transformação tecnológica emergente, escolhe localizar a apoteose da modernidade em Paris. A Inglaterra fora precursora da Revolução Industrial, e em muito precedera a França nas práticas financeiras do capitalismo especulativo. Entretanto, o que fascinava Benjamin em Paris eram as contribuições francesas para o desenho da modernidade política e cultural. "Atravessando um século de revoluções centradas em Paris, a França inventara a moderna democracia republicana e o primeiro radicalismo político moderno" (COHEN, 2004, p. 200). Paris era o lugar da gênese da cultura de massa; o espetáculo da sociedade do Ancien Régime convertera-se em manifestações sociais pósrevolucionárias; além disso, Paris era o berço da modernidade artística - representada pelo realismo e pelas vanguardas, cujas manifestações ganharam o mundo.

A cidade ostentava não apenas o luxo aristocrático, mas algo a que outras classes tinham livre acesso para olhar. Reformadas ou renovadas, com bulevares enormes sendo abertos, com árvores geometricamente ordenadas para ornar as ruas, as gran- 
33. É preciosa a anotação de Benjamin em Sobre alguns temas em Baudelaire:

“'Eis (...) o Jardin d'Hiver estabelecido desde 1845 - Avenue des Champs

Elysées - uma estufa colossal, com um

imenso espaço para reuniões sociais, para bailes e concertos, que não faz jus ao nome de jardim de inverno pois também

abre suas portas no verão. Quando a ordem planificada cria tais cruzamentos de aposentos e natureza livre, ela vem ao encontro da profunda inclinação do ser humano para a fantasia" (BENJAMIN, 1987, p. 194)

34. Benjamin, W. Gesammelte Schriften, Unter Mitwirkung von T.W.Adorno u. G.Scholem, hrsg.v. R.Tiedemann u. H. Schweppenhäuser, Frankfurt a.M.,

Suhrkamp Verlag (Bde. I-VII). 1972-1989

$[\mathrm{K} 1 \mathrm{a}, 4]$

35. Benjamin, W. Gesammelte Schriften,

Unter Mitwirkung von T.W.Adorno u.

G.Scholem, hrsg.v. R.Tiedemann u.

H. Schweppenhäuser, Frankfurt a.M.,

Suhrkamp Verlag, (Bde. I-VII). 1972-1989

[K1a,6].

36. "No século XIX começam a surgir edifícios que não devem nada ao passado.

Suas próprias linhas se originam das novas demandas apresentadas pelas grandes cidades, pela multiplicação dos meios de comunicação e por uma indústria em constante expansão" (GIEDION, 2004

p. 254).

Cadernos de Arquitetura e Utranismo, v.17, n.21, $2^{0}$ sem. 2010 des cidades eram um espetáculo para um público indiferenciado. Todos podiam passear por seus parques e jardins. As perspectivas das ruas redesenhadas acentuavam o efeito do ilusionismo na paisagem. A todos era permitido olhar as vitrines de galerias e lojas de departamento; qualquer um podia visitar museus e contemplar monumentos. Habitantes olhavam sua cidade e era assim que ela os enfeitiçava - experimentavam, como num jogo de espelhos, o deslumbramento das imagens de luxo, que resplandeciam e aparentavam estar ao alcance da mão. ${ }^{33}$

Alguns desses edifícios, quando olhados a partir dos anos de 1920, pareciam ser a substância de um sonho passado: arcadas (passagens), jardins de inverno, panoramas, fábricas, armários para figuras de cera, cassinos, estações de trem, instalações de gás, pontes.

É notável o fato de que as construções nas quais o especialista reconhece antecipações da arquitetura atual não pareçam ter nada de precursor aos olhos de um observador atento, mas não versado em arquitetura, e que, ao contrário, tenham para ele um aspecto especialmente antiquado, como pertencentes a um sonho. ${ }^{34}$

Mas ainda assim, considera Benjamin, o conhecimento desses edifícios permitiria despertar, isto é, representavam a possibilidade de educar para a consciência revolucionária.

Não só as formas em que se manifestam os sonhos coletivos do século XIX não podem ser negligenciadas, não só elas o caracterizam de maneira muito mais decisiva do que aconteceu em qualquer século anterior: elas são também, se bem interpretadas, da maior importância prática, permitindo-nos conhecer o mar em que navegamos e a margem da qual nos afastamos. É aqui, em suma, que precisa começar a "crítica" ao século XIX. ${ }^{35}$

A matéria-prima cinzenta daqueles edifícios que nada tinham a dever à história, ${ }^{36}$ em contraste com luzes e cristais das lojas, dos cafés e teatros, permitia vislumbrar o que a ditadura burguesa do Segundo Império ocultava: que havia um mundo da produção de coisas, que havia relações de produção e trabalho, e não somente consumidores e ornamentos nas salas e mobiliários suntuosos. As ambiguidades do mundo do capitalismo que permitem, nas relações econômicas, que algo signifique o contrário do que deveria, apareciam também na esfera cultural da metrópole, ou seja, na superestrutura.

A embriaguez e a ficção a que se entregou o século XIX deixavam-se representar na grande cidade, como expressão adequada àquela situação opaca, portadora de uma significação insuspeitada para a percepção e para o pensamento, e estreitamente relacionada aos fenômenos econômicos. A metrópole resultava num ambiente difuso, mas capaz de excitar a imaginação a ponto de formar e constituir a atmosfera mental coletiva.

A cidade produzida no século XIX mostrava às primeiras décadas do século XX sua origem, por isso é que deviam se tornar visíveis em 1930, quando Benjamin escreve. Em sua arqueologia da modernidade, concedia à política e à cultura um lugar privilegiado por causa do seu próprio comprometimento com a vanguarda política e cultural de seu próprio tempo - cujas aspirações radi- 
37. Formado por John Hartfield, Brecht, Piscator e Reinhardt.

38. Essa posição é certamente devedora de Bertolt Brecht. cais ele partilhava. Àquela época Berlim, como uma nova Paris, por assim dizer, atraía "artistas e personagens como um imã". Para Berlim convergiam tanto a arte de vanguarda como teorias políticas de esquerda; a cidade era um laboratório para aquela estética politicamente comprometida com a revolução marxista (BUCK-MORSS, 1977, p. 20). A proximidade de Walter Benjamin em relação ao chamado círculo marxista de Berlim, ${ }^{37}$ para o qual a arte nunca era um epifenômeno determinado pela conjuntura econômica, reforçou e atualizou sua elaboração conceitual a princípio ocupada com o Romantismo alemão. Também no contexto do século XX era possível ver quão poderoso medium-dereflexão é a arte; e, como tal, é conhecimento. A arte educa para além do que está contido nas obras. Benjamin acreditava que as novas técnicas estéticas, de que se valiam as artes do século XX poderiam ser refuncionalizadas. Eram ferramentas burguesas, que, dialeticamente transformadas em revolucionárias, permitiriam fazer emergir uma consciência crítica acerca da natureza da sociedade (BUCK-MORSS,1977, p. 20). ${ }^{38}$ Essas novas estéticas encontravam seu melhor delineamento em meio à vida urbana.

Ao tomar a cidade como um Reflexionsmedium, Benjamin fazia jus ao modo como concebeu a relação infraestrutura/superestrutura - sem muitas mediações, conforme escreveu Leandro Konder: "Benjamin se dispunha a acompanhar Adorno e Horkheimer, em matéria de conhecimento, apenas até certo ponto - uma vez que estes adotavam uma perspectiva sofisticada, exigindo uma complexa articulação dos processos e dos fenômenos em todas as suas múltiplas - infindáveis - mediações." Benjamin, para quem as ligações entre as coisas não deveriam necessariamente ser reconstituídas em todos os seus estágios, "se deixava possuir por certa urgência, por certa avidez, que o implica na direção de um encontro direto com a realidade prática".

Benjamin aterrissava sempre, colocando em terra firme a sua dialética materialista, que se baseava no reconhecimento de que os fenômenos da arte e da cultura em geral (arquitetura incluída) podem sempre ser imediatamente relacionados aos fenômenos do desenvolvimento material. Ao tratar da cidade, o filósofo colocava-se próximo às vidas minúsculas dos homens comuns, para desvelar a crítica social contida nas obras da arquitetura urbana, na maioria das vezes não facilmente perceptível. Para usar as palavras de Konder, "uma certa grossura, acreditava Benjamin, era imprescindível" (KONDER, 1999, p. 72 et seq.).

\section{Referências}

BENJAMIN, W. Announcement of the Journal Angelus Novus. Selected Writings, v. 1, p. 293, 2004.

Benjamin, W. Gesammelte Schriften. Frankfurt am Main: Suhrkamp, 1972.

BENJAMIN, W. O conceito de crítica de arte no Romantismo alemão. São Paulo: Iluminuras, 2000.

BENJAMIN, Walter. Charles Baudelaire: um lírico no auge do capitalismo. São Paulo: Brasiliense, 1989. (Obras escolhidas 3).

BENJAMIN, Walter. Magia, tecnica, arte e politica: ensaio so- 
bre literatura e historia da cultura. 3. ed. São Paulo: Brasiliense, 1987. (Obras escolhidas 2).

BLANCHOT, Maurice. Everyday speech. Yale French Studies, v. 73, p. 12-20, 1987.

BOLLE, Willi. A metrópole como medium-de-reflexão. In: SELIGMANN-SILVA, M. (Org.). Leituras de Walter Benjamin. São Paulo: Fapesp, 1999.

BUCK-MORSS, Susan. Dialética do olhar. Belo Horizonte: UFMG, 2002.

BUCK-MORSS, Susan. The origin of negative dialectics: Theodor W. Adorno, Walter Benjamin and the Frankfurt Institute. New York: Macmillan Free Press, 1977. p. 20.

CAUNE, Jean. L'expérience esthétique: un concept à construire. In: CAUNE, Jean. Esthétique de la communication. Paris: Puf, 1997.

CLAUDE, Amey. Experiência estética e agir comunicativo. Novos Estudos Cebrap, n. 29, p. 131-147, março 1991.

COHEN, M. Benjamin's phantasmagoria: the Arcades project. In: FERRIS, D. (Ed.). The Cambridge companion to Walter Benjamin. Cambridge: Cambridge University Press, 2004. p. 200.

FERRARIS, Maurizio. Estética, hermenêutica, epistemologia. In: GIVONE, Sérgio. Historia de la estética. Madrid: Tecnos Editorial, 1990. p. 171-214.

GADAMER, H.-G. Palavra e imagem. In: GADAMER, H.-G. Estética y hermenéutica. Mexico: Taurus Editorial, 1998. p. 279-307.

GADAMER, H.-G. Wahrheit und Methode. Tübingen: Mohr, 1960.

GAGNEBIN, Jeanne-Marie. Nas fontes paradoxais da crítica literária. Walter Benjamin relê os românticos de lena. In: SELIGMANN-Silva, M. (Org.). Leituras de Walter Benjamin. São Paulo: Fapesp, 1999. p. 68; 73.

GIEDION, Sigfried. Espaço, tempo e arquitetura. São Paulo: Martins Fontes, 2004.

GÓMEZ-HERAS, J. M. G. El a priori del mundo de la vida: Fundamentación fenomenológica de una ética de la ciencia y de la técnica. Barcelona: Anthropos, 1989.

HUCHET, S. Horizonte tectônico e campo plástico. De Gottfried Semper ao grupo Archigram: pequena genealogia fragmentária. In: MALARD, M. L. (Org.). Cinco textos sobre arquitetura. Belo Horizonte: UFMG, 2005. p. 169-234.

Hughes, Fiona. Três dimensões espaciais na estética de Kant. In: Ceron, I.; Reis, P. (Ed.). Kant: crítica e estética na modernidade. São Paulo: Senac, 1999.

HUSSERL, E. Philosophy in the crisis of European mankind: Lecture delivered by Edmund Husserl, Vienna, 10 May 1935; therefore often referred to as: "The Vienna Lecture". 115k. Disponível em: http://www.users.cloud9.net/ bradmcc/husserl_philcris. html. Acesso em: 21 dez. 2010.

ISER, Wolfgang. O ressurgimento da estética. In.: ROSENFIELD, Denis L. (Org.). Ética e estética. Rio de Janeiro: Zahar, 2001. (Filosofia política. Série III, n. 2). 
JAUSS, H. R. Experiencia estética y hermenéutica literária. Madrid:Taurus, 1986.

KONDER, Leandro. Walter Benjamin: o marxismo da melancolia. 3. ed. Rio de Janeiro: Civilização Brasileira, 1999.

KRACAUER, Siegfried. The mass ornament. New York: Verso, 1979 .

LEACH, N. Rethinking architecture. London: Routledge, 1999.

LEFEBVRE, H. Critique of everyday life. New York: Verso, 1991.

LEFEBVRE, H. O direito à cidade. São Paulo: Moraes, 1968.

LUKÁCS, G. História e consciência de classe. São Paulo: Martins Fontes, 2003.

MADSEN, Peter. Introduction. In: MADSEN, Peter. The urban lifeworld. Formation, perception, representation. London: Routledge, 2002.

MARX, K. O processo de produção do capital. In: MARX, K O capital. Crítica da economia política, Livro 1, volume 1. Rio de Janeiro: Civilização Brasileira, 2004.

MERQUIOR, J. G. Arte e sociedade em Marcuse, Adorno e Benjamin. Rio de Janeiro: Tempo Brasileiro, 1969.

PÉREZ-GÓMEZ Alberto. Prefacio. In: STEVEN, Holl. El croquis. Madrid: El Croquis Editorial 1999.

PIAGET, J. Perceptual and cognitive (or operational) structures in the development of the concept $f$ space in the child. In: INTERNATIONAL CONGRESS OF PSYCHOLOGY, 14, 1964, Philadelphia, PA. Proceedings of the XIV International Congress of Psychology. Philadelphia, PA: International University Press 1964. p. 1-43

SCHOLEM, G.; BENJAMIN, W. Correspondência. São Paulo: Perspectiva, 2004.

TAFURI, Manfredo. Projeto e utopia. Lisboa: Editorial Presença, 1989.

TSCHUMI, B. Advertisements for architecture. In: TSCHUMI, B. The Manhattan transcripts. London: Academy Editions, 1994.

WOLLEN, Peter. Bitter victory: the art and politics of the situationist international, published in Elisabeth Sussman. In: WOLLEN, Peter. On the passage of a few people through a rather brief moment in time: the situationist international 1957-1972. Boston: ICA, 1989.

ZUMTHOR, P. Performance, recepção, leitura. São Paulo: Educ, 2000.

\section{Endereço para correspondência}

Rita de Cássia Lucena Velloso

Opur/ ProEx - PUC Minas

Av. Dom José Gaspar, 500, Prédio 30

ritavelloso@gmail.com 


\section{SUBMISSÃO DETRABALHOS}

A submissão de novos trabalhos deverá ser feita por meio do Portal de Periódicos Eletrônicos da PUC Minas, no site http://periodicos.pucminas.br/index.php/arquiteturaeurbanismo, onde estão disponibilizadas as normas para apresentação de trabalhos, também em inglês e espanhol.

\section{NORMAS PARA APRESENTAÇÃO DE TRABALHOS}

1. Serão aceitos para apreciação trabalhos das seguintes modalidades:
a) artigos de revisão relacionados às diversas áreas temáticas da arquitetura e urbanismo;
b) artigos de pesquisa que apresentem novas contribuições para a arquitetura e urbanismo;
c) artigos associados a dissertações de mestrado e teses de doutorado;
d) artigos relacionados ao ensino de arquitetura e urbanismo;
e) resenhas de livros, artigos e filmes de significativa importância para a arquitetura e urbanismo;
f) projetos de arquitetura e urbanismo, discutidos teórica e metodologicamente;
g) entrevistas.

2. Só serão aceitos trabalhos inéditos e ainda não publicados.

3. A critério do Conselho Editorial poderão ser aceitos trabalhos que não se enquadrem nos itens acima, considerada a sua especial relevância.

4. Os trabalhos deverão atender as seguintes especificações:

a) Trabalho digitado em Word for Windows, fonte Times New Roman, corpo 12, entrelinha 1,5, em formato A4, com margens superior, inferior e direita de $2 \mathrm{~cm}$, e margem esquerda de $3 \mathrm{~cm}$.

b) O trabalho completo (incluindo resumos, notas, ilustrações e referências bibliográficas) deverá ter no mínimo 12 e no máximo 20 páginas.

c) Título e subtítulo objetivos, de no máximo 50 caracteres, apresentado de modo bilíngüe (português / inglês).

d) Caso o trabalho seja decorrente de pesquisas, dissertações, teses ou similares, explicitar em nota de rodapé associada ao título.

e) Nome completo do autor ou autores, complementado com as seguintes informações, indicadas em nota de rodapé (uma para cada autor): formação/instituição, titulação/instituição, filiação profissional.

f) Resumo do trabalho, apresentado de modo bilíngüe (português/inglês), contendo no máximo 500 caracteres cada.

g) Palavras-chave / key words (mínimo de 3 e máximo de 5), apresentadas de modo bilíngüe (português/inglês).

h) Citações, notas e referências bibliográficas devem ser apresentadas segundo as normas da ABNT.

i) As notas devem ser de rodapé.

j) As imagens de qualquer natureza (gráficos, figuras, fotos, mapas e outras) devem ser perfeitamente legíveis em preto e branco e apresentadas de duas maneiras:

- Ao longo do texto, em baixa resolução, numeradas, acompanhadas de legendas específicas, em Times New Roman, tamanho 10, com identificação de fonte (as imagens não podem, em hipótese alguma, ter problema de direitos autorais).

- Cada uma das imagens inseridas ao longo do trabalho deve ainda ser submetida pelo sistema, conforme consta no "Passo 4: Envie Documento Suplementar". Elas devem estar em formato JPG ou TIF, com tamanho real de no mínimo 1000 pixels na horizontal e altura proporcional, de modo a garantir boa qualidade para reprodução gráfica.

k) Endereço completo para correspondência (com CEP) e e-mail, de cada um dos autores, inseridos ao final do trabalho.

5. A identificação de autoria do trabalho será removida do arquivo pela equipe editorial para avaliação por pares, garantindo desta forma o critério de sigilo da revista.

6. Não serão aceitos trabalhos que não atendam as especificações e exigências acima.

\section{CONDIÇÕES GERAIS}

A colaboração não é remunerada.

O artigo ficará disponibilizado por tempo indeterminado.

O site dos Cadernos de Arquitetura e Urbanismo permite acesso aos artigos por links diretos. 


\section{NORMS FOR SUBMISSION OF PAPERS}

1. The following kinds of papers will be accepted for evaluation:
a) review articles related to the various thematic areas of architecture and urbanism;
b) research articles that represent new contributions to architecture and urbanism;
c) articles related to master's dissertations and doctoral theses;
d) articles about the teaching of architecture and urbanism;
e) book, article and film reviews of relevance to architecture and urbanism;
f) architectural and urbanistic designs, theoretically and methodologically discussed;
g) interviews.

2. Only original and unpublished papers will be accepted.

3. The Editorial Board can accept particularly relevant papers not included in the categories mentioned above.

4. Papers must meet the following specifications:

a) Text typed in Word for Windows; font Times New Roman, size 12, line space 1.5 in A4 format; top, bottom and right margins of $2 \mathrm{~cm}$ and left margin of $3 \mathrm{~cm}$.

b) The whole paper (including abstract, notes, illustrations and references) must have a minimum of 12 and a maximum of 20 pages.

c) Objective title and subtitle, maximum of 50 characters, presented in Portuguese and in English.

d) For papers resulting from research, dissertations or theses, it must be indicated in a footnote associated to the title.

e) Author's or authors' full name(s), with the following information in a footnote: qualification / institution, title / institution, professional affiliation.

f) Abstract in Portuguese and in English, containing a maximum of 500 characters each.

g) Key words (minimum 3 and maximum 5) in English and in Portuguese.

h) Quotations, footnotes and references must comply with the ABNT norms.

i) Notes must be presented as footnotes.

j) Images of any type (graphics, pictures, photos, maps and others) must be perfectly legible in black and white and presented in two ways:

- Throughout the text, in low resolution, numbered, with specific legends in Times New Roman, size 10, followed by source (pictures cannot have, under any circumstances, copyright claims);

- Each image inserted along the text must still be put through the system, as shown in "Step 4: Upload supplementary document." The images must be in JPG or TIF format, with a size of at least 1000 horizontal pixels and proportional height so as to ensure good quality for graphic reproduction.

k) Complete mailing address (with zip code) and e-mail of each author, inserted at the end of the paper.

5. The identification of the paper authorship will be removed from the file by the editorial team, thus ensuring the criterion of confidentiality of the journal.

6. Papers that do not meet the specifications and requirements above will not be accepted.

\section{GENERAL CONDITIONS}

The collaboration is unpaid.

The article will be available indefinitely.

The site of the Journal of Architecture and Urban Design allows access to articles by direct links. 


\section{DIRECTRICES DE DOCUMENTOS}

1. Se aceptarán trabajos para evaluación de los siguientes tipos:
a) artículos de revisión relacionados a las diversas áreas temáticas de la arquitectura y urbanismo;
b) artículos de pesquisa que presenten nuevas contribuciones para la arquitectura y urbanismo;
c) artículos asociados a disertaciones de master y a tesis de doctorado;
d) artículos relacionados a la enseñanza de arquitectura y urbanismo que relaten nuevas experiencias didáctico- pedagógicas;
e) resúmenes de libros, artículos y películas de significativa importancia para la arquitectura y urbanismo;
f) proyectos de arquitectura y urbanismo, discutidos teórica y metodológicamente;
g) entrevistas.

2. Sólo se aceptarán trabajos inéditos, aún no publicados.

3. A criterio del Consejo Editorial, podrán aceptarse trabajos que no se encuadren en los puntos arriba indicados dada su especial relevancia.

4. Los trabajos deberán tener las siguientes especificaciones:
a) Digitalizado en fuente Word for Windows, tipo Times New Roman, cuerpo 12, interlineado 1,5 en papel tamaño A4, márgenes superior, inferior y derecho de $2 \mathrm{~cm}$ y margen izquierdo de $3 \mathrm{~cm}$.
b) El trabajo completo (incluyendo resúmenes, notas, ilustraciones y referencias bibliográficas) deberá tener como mínimo 12 y como máximo 20 páginas.
c) Título y subtítulo objetivos, con un máximo de 50 caracteres, presentado de modo bilingüe (Español / Inglés).
d) Si el trabajo es consecuencia decurrente de investigaciones, disertaciones, tesis o similares, debe explicitárselo en nota de pie de página asociada al título.
e) Nombre completo del autor o autores, complementado con las siguientes información, indicadas en nota de pie de página: formación / institución /, titulación / institución/, afiliación profesional.
f) Resumen presentado en forma bilingüe (Español / Inglés), con un máximo de 500 caracteres cada.
g) Palabras clave (mínimo de 3 y máximo de 5), presentados en modo bilingüe (Español / Inglés) (palabras clave / key words).
h) Citas, notas y referencias bibliográficas presentados según las normas de la ABNT.
i) Las notas deberán ser de pie de página.
j) Las imágenes de cualquier tipo (gráficos, imágenes, fotos, mapas y otros) deberán ser perfectamente legibles en blanco y negro y se presenta en dos formas:
- A lo largo del texto, de baja resolución, numeradas, acompañadas de leyendas específicas en Times New Ro- man, cuerpo 10, donde deben constar las fuentes (las imágenes no pueden, bajo ninguna circunstancia, tener problemas con los derechos de autor).
- Cada una de las imágenes incluidas a lo largo de la obra aún debe ser insertado por medio del sistema, como se muestra en el "Paso 4: Cargar complementaria." Deben estar en formato JPG o TIF, con un tamaño mínimo de 1000 píxeles horizontales y altura proporcional, para asegurar buena calidad de reproducción gráfica.
k) Dirección postal completa y e-mail (indicados para cada autor al final del trabajo).

5. La identificación de la autoría de la obra será retirada de los autos por el equipo editorial, lo que garantiza la confidencialidad de los criterios revisados.

6. No se aceptarán trabajos que no cumplan las especificaciones y exigencias arriba indicadas.

\section{CONDICIONES GENERALES}

La colaboración no es remunerada.

El artículo estará disponible por tiempo indefinido.

El sitio de la Revista de Arquitectura y Urbanismo permite el acceso a artículos por enlaces directos. 


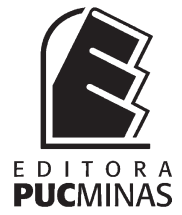

Outros periódicos da Editora PUC Minas

\section{BIOS}

Departamento de Ciências Biológicas

\section{CADERNOS CESPUC DE PESQUISA}

Caderno do Programa de Pós-graduação em Letras e do Cespuc

\section{CADERNO DE GEOGRAFIA}

Departamento de Geografia

\section{CADERNOS DE HISTÓRIA}

Departamento de História

\section{ECONOMIA \& GESTÃO}

Revista do Programa de Pós-graduação em Administração e do Instituto de Ciências Econômicas e Gerenciais

\section{FRONTEIRA}

Revista de Iniciação Científica em Relações Internacionais

\section{HORIZONTE}

Revista do Núcleo de Estudos em Teologia e Ciências da Religião

\section{PSICOLOGIA EM REVISTA}

Revista do Instituto de Psicologia

\section{REVISTA DA FACULDADE MINEIRA DE DIREITO}

Faculdade Mineira de Direito

\section{SCRIPTA}

Revista do Programa de Pós-graduação em Letras e do Cespuc 


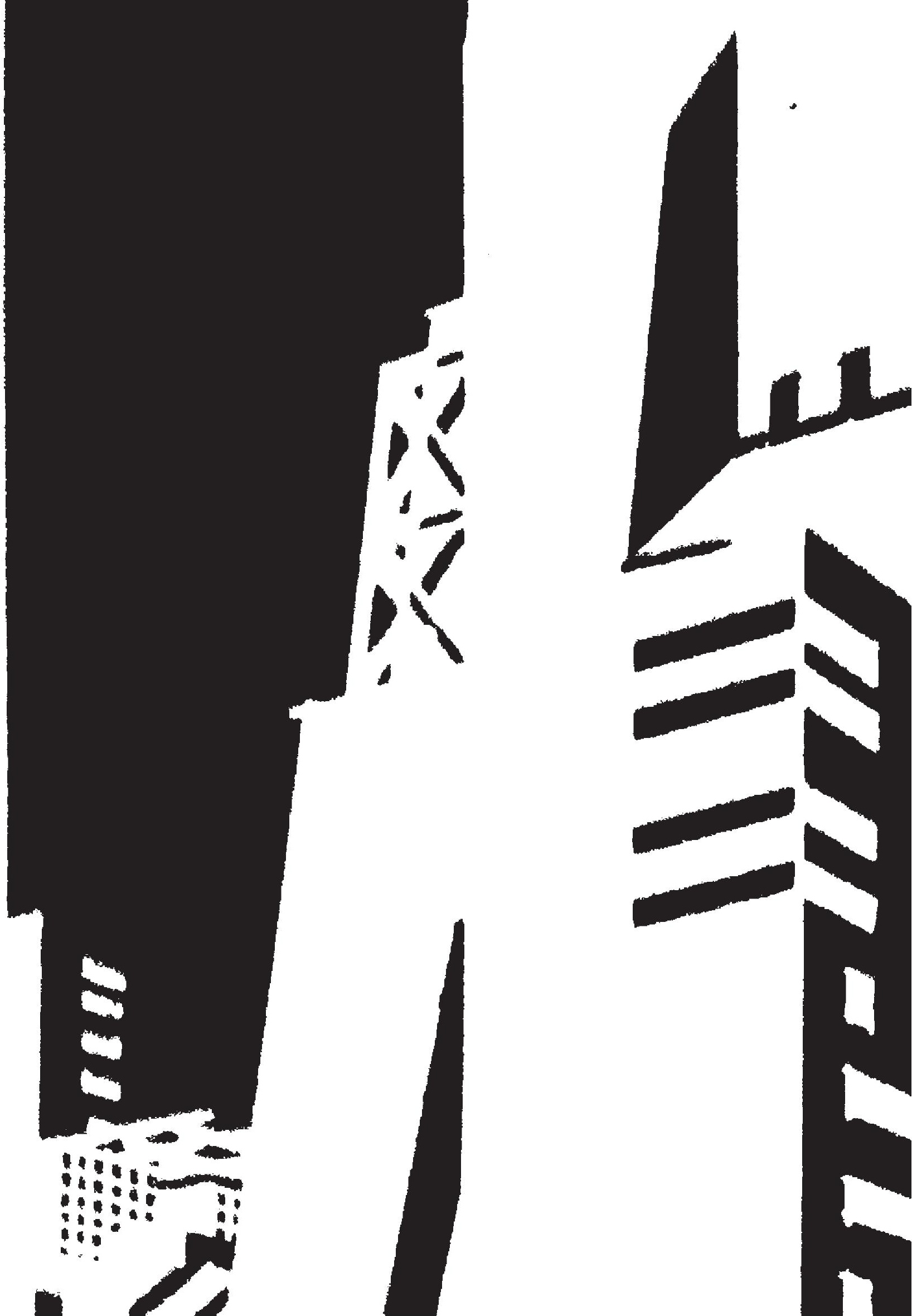

